Western Washington University Western CEDAR

\title{
Characteristics of Students in Traditional Versus Alternative High Schools: A Cross-Sectional Analysis of Enrollment in One Urban District
}

\author{
Aaron B. Perzigian \\ Western Washington University, aaron.perzigian@wwu.edu \\ Kemal Afacan \\ Whitney Justin \\ Kimber L. Wilkerson
}

Follow this and additional works at: https://cedar.wwu.edu/woodring_dei

Part of the Education Commons

\section{Recommended Citation}

Perzigian, A. B., Afacan, K., Justin, W., \& Wilkerson, K. L. (2017). Characteristics of Students in Traditional Versus Alternative High Schools: A Cross-Sectional Analysis of Enrollment in One Urban District. Education and Urban Society, 49(7), 676-700. https://doi.org/10.1177/0013124516658520

This Article is brought to you for free and open access by the Woodring College of Education at Western CEDAR. It has been accepted for inclusion in Woodring Scholarship on Diversity, Equity, Inclusion by an authorized administrator of Western CEDAR. For more information, please contact westerncedar@wwu.edu. 


\title{
Characteristics of Students in Traditional \\ Versus Alternative \\ High Schools: A \\ Cross-Sectional Analysis \\ of Enrollment in One \\ Urban District
}

\section{Aaron B. Perzigian', Kemal Afacan², Whitney Justin', and Kimber L. Wilkerson²}

\begin{abstract}
Urban school districts are comprised of many diverse high school environments including comprehensive neighborhood schools as well as a variety of smaller alternative models that focus on innovative practices, behavior remediation, or academic recovery. In terms of enrollment distribution, urban school districts are increasingly offering nontraditional school placement options for students presenting academic and behavioral difficulty or for students seeking specific curricular emphasis or pedagogy, including - but not limited to-use of school choice voucher programs. In this study, we examined student distribution across school types in one large urban district to investigate enrollment patterns with regard to gender, race, socioeconomic status, and disability status. The results of this cross-sectional analysis indicated significant disproportionality in student demographics within different school types, including overrepresentation of
\end{abstract}

'Western Washington University, Bellingham, WA, USA

2University of Wisconsin-Madison, WI, USA 
African American students, male students, and students with disabilities in restrictive and segregated alternative schools; overrepresentation of White students and female students in self-selected and innovative alternative schools; and underrepresentation of Hispanic and Asian students in remedial alternative schools. Implications of this disproportionality for policy and practice are discussed.

\section{Keywords}

accountability, urban education, educational policy, school choice, social justice

School districts offer a variety of educational settings in which students can pursue a high school diploma or certificate. These include traditional comprehensive neighborhood schools as well as alternative schools tailored to special interests or more intensive student needs. While traditional schools are characterized by a varied curriculum and breadth of class options, alternative schools tend to offer more focused curricular content, learning contexts, or teaching methodologies from that which is typical in traditional settings. As an umbrella term, alternative education is conceptualized as comprised of schools and programs dedicated to serving students who have become disengaged in the traditional model or are experiencing chronic academic and behavioral difficulty (Gold \& Mann, 1982; Lehr, Tan, \& Ysseldyke, 2009; Raywid, 1994). In some cases, alternative signifies an innovative approach to education. However, alternative also describes those tracks of education reserved for students failing in their neighborhood school and in need of remedial academic or behavioral intervention.

Past research categorized alternative secondary schools into three broad types: schools of choice, behavior reassignment, and academic recovery (Raywid, 1994). Alternative schools of choice offer discrete content (e.g., arts, business, or technology focused) and students are frequently required to apply and gain acceptance to attend them. These schools may also be associated with innovative teaching philosophies (e.g., Waldorf and Montessori) uncommon in traditional school environments. For the purpose of this study, schools of choice are termed innovative alternative schools. In sharp contrast, alternative schools with a behavior focus are regarded as a last resort for students presenting challenging behavior. These settings emphasize behavioral remediation and are often a student's final option before expulsion from a district. The term behavior-focused represents these schools in the present study. Academic recovery alternative schools provide academic remediation 
and are locales for students who experience credit deficiencies or are otherwise off-track academically toward high school completion. These schools often provide individualized instruction, frequently in an online or computerbased format, to address the performance gaps in students' pursuit of a high school diploma or other completion document. These are termed academic remediation-focused alternative schools.

Processes of referral and admissions to differing types of alternative schools vary by district. In the district for the present study, enrollment in innovative alternative schools is student driven: Students are responsible for choosing these school options and satisfying the admissions criteria. For example, the sample district operates a highly competitive performing arts high school. To attend this innovative alternative school, prospective students must meet standard grade point criteria and must also audition in their performing arts area (e.g., dance or violin). Due to the nature of the admissions process to many innovative alternative schools, enrollment can be exclusionary for certain groups of students (e.g., youth with academic deficiency, youth with perceived behavior concerns, or youth without prior arts exposure), which may deny access for the very students who might benefit most from these typically more rigorous settings.

Conversely, enrollment in behavior-focused alternative schools is determined by school referral, sometimes in collaboration with a student's family, social worker, probation officer, or juvenile court judge. For example, the sample district operates an alternative day treatment school for students with severe behavior difficulty who attend on the basis of juvenile court referral. Students do not, on their own accord, attend behavior-focused alternative schools. In the sample district, students enrolled in academic remediationfocused alternative schools can be referred by their neighborhood school, or can enroll on account of their own choice, often in concert with encouragement from a guidance counselor. These are not settings attended by students "in trouble" for poor behavior, such as the alternative schools aimed at behavior modification. Thus, referral is theoretically rooted in academic need. It is most typical that students enroll for at least one semester in their traditional neighborhood school prior to transitioning to an alternative school of choice or referral. However, some innovative alternative schools in the sample district do permit enrollment in the first semester of ninth grade.

It is not uncommon in the sample district for students who enroll in an alternative school to do so temporarily and eventually transition back to their traditional neighborhood school. For example, there are instances when a student attends an alternative school with a behavior focus for a semester and then returns to the school from which he was originally referred at the beginning of the following academic year. Similarly, students choosing or referred 
to attend an academic remediation-focused alternative school may do so temporarily and again return to their homeschool. Furthermore, some students might transition from one alternative school to another alternative school if it is determined that an additional alternative placement would best meet their needs.

The majority of students nationwide attend traditional neighborhood schools (Keaton, 2014). However, in urban areas, an increased number of students are educated outside the traditional school model. For example, Lehr et al. (2009) asserted that the number of students at risk for school failure who are attending nontraditional schools is significant and that data trends indicate continued enrollment growth in these settings, especially in districts serving large percentages of non-White youth. Moreover, urban school districts, including the sample district in the present study, serve larger proportions of students presenting academic or behavioral difficulty as well as a student body that is at increased drop-out risk when compared with suburban and some rural districts (Lippman, Burns, \& McArthur, 1996; McCurdy, Kunsch, \& Reibstein, 2007). Urban school districts are also more likely to operate nontraditional schools in an attempt to meet the needs of their students, which is evident in the sample district based on its numbers of alternative schools. Verdugo and Glenn (2006) reported that $66 \%$ of urban districts operate nontraditional school settings in comparison with $41 \%$ of suburban districts and $35 \%$ of rural districts.

While research on educational outcomes related to specific types of secondary schools is limited, some evidence suggests disparate academic and behavioral outcomes for students enrolled in academically remedial or behavior modification alternative schools, including lower scores on standardized tests of math and reading, lower numbers of credits earned, poorer school attendance, and higher rates of dropout, when compared with students enrolled in traditional schools (Carruthers \& Baenen, 1997; Chiang \& Gill, 2010; Dugger \& Dugger, 1998; Tenenbaum, 2000; Wilkerson, Afacan, Perzigian, Justin, \& Lequia, 2016). In light of the disparate outcomes for students who attend some alternative schools, this body of work raises concern about who is educated in which type of schooling placement, and the characteristics and opportunities associated with those settings.

The current charter school movement has resulted in growing numbers of alternative school options in communities across the United States. Founded on school choice reform, charter schools have greatly increased the number and variety of K-12 learning environments. They are utilized as a public alternative in 40 states and have grown in numbers from 1,800 schools in 2000 to approximately 6,000 in 2012 (National Alliance for Public Charter Schools, 2013). Past research suggests urban districts with heavier use of 
charter schools are associated with increased racial segregation across schools (Renzulli \& Evans, 2005), which serves as a reminder that changes in the landscape of alternative school offerings may come with unanticipated changes in service delivery to students.

It should be noted that legislation also fuels some proliferation of school types. For example, the No Child Left Behind Act (2003) provides parents with school mobility opportunities if their child's current school fails to make adequate yearly progress (AYP). New placement options available to families range from innovative alternative schools to successful (indicated by AYP) traditional high schools. Critics have noted, however, that in practice, school choice may exacerbate racial segregation within school districts and across school types: A disproportionate number of students from low socioeconomic status (SES) and non-White families elect to stay enrolled in lowperforming urban schools in which larger proportions of minority youth are served, in part, because these parents prefer their children to be educated alongside students from similar financial and racial or ethnic backgrounds (Davis, 2012). In addition, school choice may act as a vehicle for families of White students to choose schools that serve greater proportions of White youth (Bifulco, Ladd, \& Ross, 2009; Henig, 1996; Saporito, 2003), which further increases racial gaps across some districts' schools. Given that the public educational landscape includes numerous school placement optionsand districts have instituted application procedures for many innovative alternative schools - the risk of creating segregated settings and inequality of opportunity are increased.

Discrepancies in enrollment patterns with regard to student demographics, if they exist, could signify unequal access to certain educational opportunities associated with specific school types and overreliance on more deep-end, restrictive settings to serve subgroups of students. Because some districtsparticularly those serving larger percentages of minority students - are more likely to rely on alternative settings (e.g., Verdugo \& Glenn, 2006), research is needed to disaggregate and examine student enrollment by type of alternative school setting. Whether youth attend a particular school by default due to neighborhood boundaries, individual choice, or school referral, variance in enrollment by school type with regard to student ethnicity, gender, SES, and disability status may indicate ways in which districts utilize or rely upon different educational settings and for whom. Awareness of potential discrepancies can inform district and school policies as well as instructional decisions aimed at maximizing educational equity.

The purpose of this research is to analyze student enrollment patterns across types of public secondary schools in one large urban district. Specifically, this research addresses the following research question: 
Research Question 1: Do the proportions of students enrolled in different types of secondary schools vary significantly with regard to demographic variables?

Student demographic characteristics examined include
a. Gender,
b. Ethnicity,
c. Student SES (qualification for free or reduced price lunch [FRL]), and
d. Disability status.

\section{Method}

\section{Setting}

Census data indicate a population of 750,000 in the city in which the sample district is located, with $20 \%$ to $25 \%$ living at or below the national poverty line. Approximately $40 \%$ of the population identifies as African American, $38 \%$ as White (non-Hispanic), and $17 \%$ as Hispanic or Latino, and the median family income is US $\$ 35,000$ to US $\$ 40,000$. The sample school district serves about $70,000 \mathrm{~K}-12$ students each year. According to the state education agency (SEA), $85 \%$ of the students in the district are economically disadvantaged, defined as qualifying for FRL. Furthermore, the SEA indicates that the 2012-2013 high school completion percentage (with a regular diploma) in the district was about $65 \%$ and that approximately $80 \%$ of the district's 10 thgrade students did not meet proficiency on standardized assessments of reading and mathematics during the 2012-2013 academic year.

\section{Sample}

This study used longitudinal data, and our overall sample included data from 21,165 students enrolled in Grades 9 to 12 during the 2012-2013 school year. Data were comprised of information regarding each student's current educational placement; gender, race, and ethnicity; FRL status; and disability status. Table 1 provides a summary of demographic characteristics of the student sample. The student sample is predominantly African American, and the majority of students $(80.4 \%)$ qualified for FRL during the data collection year.

\section{School Coding Procedure}

School coding was necessary to determine the frequency and distribution of student enrollment in the different types of secondary schools for this analysis. 
Table I. Characteristics of Whole Sample.

\begin{tabular}{lc}
\hline Characteristic & $\%(n)$ \\
\hline Gender & \\
Female & $48.7 \%(10,308)$ \\
Male & $51.3 \%(10,854)$ \\
Ethnicity & \\
African American & $62.3 \%(13,175)$ \\
Asian & $5.6 \%(1,187)$ \\
Hispanic & $20.5 \%(4,333)$ \\
HI/PI & $0.0 \%(1)$ \\
Native American & $0.7 \%(147)$ \\
White & $11 \%(2,319)$ \\
FRL status & \\
Yes & $80.4 \%(17,007)$ \\
No & $19.6 \%(4,155)$ \\
Student disability status & \\
Yes & $22.4 \%(4,744)$ \\
No & $77.6 \%(16,4 \mid 8)$ \\
\hline
\end{tabular}

Note. Value in parentheses refers to number of students. HI/PI = Hawaiian Islander or Pacific Islander; $\mathrm{FRL}=$ free or reduced price lunch.

Researchers used a protocol to collect information about each secondary school in the district and used the resulting data to code schools into one of four school types: traditional school, innovative alternative school, behaviorfocused alternative school, and academic remediation-focused alternative school. Informational data collected for coding pertained to four factors: (a) Was the school listed as an alternative, charter, intensive, transformative, or something other than High School? (b) Do the majority of students attend by choice or by referral/assignment? (c) Does the school curricula focus on a specific skill area (e.g., international baccalaureate, arts or technology)? or Does the school target a select student demographic other than students identified at risk? and (d) Is the school aimed at academic recovery or behavior modification? Researchers referenced information provided via the district website to code each individual school and then determined the final school type based on answers to the protocol questions. It should be noted that the sample district operates one remedial alternative middle school option for students struggling in eighth grade from which a student can transfer directly to an academically remedial alternative high school. This is a small program administered by the district in collaboration with a local community college and is not included in the present study. 
Before coding schools, all coders were trained on use of the protocol. Coders were initially provided with batches of 10 schools to code. Each coder was trained until they met $90 \%$ agreement with the trainer (first author) on an item-by-item basis (i.e., responses to the individual coding prompts), as well as on the determination of final school type for each school. Discrepancies were discussed in small group format until $100 \%$ agreement was reached. Following training, two coders independently coded all 53 secondary schools in the district with $89 \%$ agreement. Disagreements were discussed in face-toface meetings by the coders until $100 \%$ agreement was reached.

Of the 53 total schools, descriptive information for nine schools was unavailable on the sample district's website. For those nine schools, a member of the research team searched for publicly available information beyond the district website. For six of the nine, sufficient information for coding was available through the individual school's home page. Information for two of the three remaining schools was obtained online via two different sources: the district's accountability website and a local newspaper database. Complete information for the final school in our sample could not be found through online search procedures. Information necessary to code that final school was retrieved verbally from a school district administrator.

\section{Analysis}

Data were analyzed using SPSS. We calculated frequency by school type for specific student demographic characteristics, including gender, ethnicity, FRL status, and disability status. Using a chi-square test of independence, we tested for significant difference at the .05 level in student distribution across four school types with regard to the selected demographic characteristics.

\section{Results}

Table 2 summarizes the number of each school type and the overall and average enrollment for each in the sample district. Table 3 provides a summary of student demographics by school type as well as a summary of significance tests of differences in proportions between the four school types. Subscript letters in Table 3 denote characteristics that differ significantly at the $\alpha=.05$ level or lower. Table 4 presents the distribution of students among federally identified special education categories across the four school types.

\section{Gender}

The overall test statistic for gender representation across school types is significant, $\chi^{2}(3, N=21162)=59.07, p=.000$. The proportion of female students 
Table 2. Secondary School Enrollment by School Type.

\begin{tabular}{lccc}
\hline School type & $\begin{array}{c}\text { Number of } \\
\text { schools }\end{array}$ & $\begin{array}{c}\text { Number of } \\
\text { students }\end{array}$ & $\begin{array}{c}\text { Average } \\
\text { enrollment }\end{array}$ \\
\hline Traditional & $9(17.0 \%)$ & $8,478(40.0 \%)$ & 942 \\
Innovative & $20(37.7 \%)$ & $11,192(52.9 \%)$ & 560 \\
Behavior-focused & $9(17.0 \%)$ & $165(0.8 \%)$ & 18 \\
Academic remediation & $15(28.3 \%)$ & $1,327(6.3 \%)$ & 88 \\
Total & $53(100 \%)$ & $21,162(100 \%)$ & \\
\hline
\end{tabular}

Note. Number of schools = how many schools identified in each school type within sample district; Number of students = how many students enrolled in each school type within sample district.

Table 3. Student Characteristics by School Type.

\begin{tabular}{|c|c|c|c|c|}
\hline Characteristic & Traditional & Innovative & $\begin{array}{l}\text { Behavior- } \\
\text { focused }\end{array}$ & $\begin{array}{l}\text { Academic } \\
\text { remediation }\end{array}$ \\
\hline \multicolumn{5}{|l|}{ Gender } \\
\hline Female & $46.5 \%(3,943)_{a}$ & $50.7 \%(5,67 \mathrm{I})_{\mathrm{b}}$ & $29.1 \%(48)_{c}$ & $48.7 \%(646)_{a, b}$ \\
\hline Male & $53.5 \%(4,535)_{\mathrm{a}}$ & $49.3 \%(5,521)_{b}$ & $70.9 \%(1 \mid 7)_{c}$ & $51.3 \%(68 I)_{a, b}$ \\
\hline \multicolumn{5}{|l|}{ Ethnicity } \\
\hline $\begin{array}{l}\text { African } \\
\text { American }\end{array}$ & $6 \mid .2 \%(5, \mid 85)_{a}$ & $59.9 \%(6,70 \mathrm{I})_{\mathrm{a}}$ & $81.2 \%(134)_{b}$ & $87 \%(I, I 55)_{b}$ \\
\hline Asian & $5.8 \%(49 I)_{a}$ & $6.1 \%(683)_{a}$ & $0.6 \%(I)_{b}$ & $0.9 \%(12)_{b}$ \\
\hline $\mathrm{HI} / \mathrm{PI}$ & $0 \%(0)_{a}$ & $0 \%(I)_{a}$ & $0 \%(I)_{a}$ & $0 \%(0)_{a}$ \\
\hline Hispanic & $22.8 \%(1,937)_{a}$ & $20.4 \%(2,283)_{b}$ & $9.7 \%(16)_{c}$ & $7.3 \%(97)_{c}$ \\
\hline $\begin{array}{l}\text { Native } \\
\text { American }\end{array}$ & $0.9 \%(75)_{a}$ & $0.6 \%(64)_{a}$ & $\mathrm{I} .2 \%(2)_{\mathrm{a}}$ & $0.5 \%(6)_{a}$ \\
\hline White & $9.3 \%(790)_{a}$ & $13 \%(1,460)_{b}$ & $7.3 \%(12)_{c}$ & $4.3 \%(57)_{\mathrm{c}}$ \\
\hline \multicolumn{5}{|l|}{ FRL status } \\
\hline Yes & $85.1 \%(7,218)_{a}$ & $76.9 \%(8,6 \mathrm{II})_{\mathrm{b}}$ & $66.1 \%(109)_{c}$ & $80.6 \%(1,069)$ \\
\hline No & $14.9 \%(1,260)_{\mathrm{a}}$ & $23.1 \%(2,58 \mathrm{I})_{\mathrm{b}}$ & $33.9 \%(56)_{c}$ & $19.4 \%(258)_{d}$ \\
\hline \multicolumn{5}{|c|}{ Special Ed. status } \\
\hline Yes & $23.8 \%(2,016)_{a}$ & $21.2 \%(2,372)_{b}$ & $57.0 \%(94)_{c}$ & $19.7 \%(262)_{b}$ \\
\hline No & $76.2 \%(6,462)_{a}$ & $78.8 \%(8,820)_{b}$ & $43.0 \%(7 I)_{c}$ & $80.3 \%(1,065)_{b}$ \\
\hline
\end{tabular}

Note. Value in parentheses refers to number of students. Means with differing subscripts within rows are significantly different at $p<.05$. HI/PI= Hawaiian Islander or Pacific Islander; $\mathrm{FRL}=$ free or reduced price lunch; Special Ed. = students receiving special education services.

attending traditional (46.5\%) versus innovative alternative schools (50.7\%) differs significantly. In addition, the distribution of female students differs significantly between traditional and behavior-focused alternative schools 
Table 4. Disability Categories by School Type.

\begin{tabular}{|c|c|c|c|c|}
\hline $\begin{array}{l}\text { Disability } \\
\text { categories }\end{array}$ & Traditional & Innovative & $\begin{array}{l}\text { Behavior- } \\
\text { focused }\end{array}$ & $\begin{array}{l}\text { Academic } \\
\text { remediation }\end{array}$ \\
\hline Autism & $2.9 \%(59)_{a}$ & $5.1 \%(120)_{b}$ & $6.4 \%(6)_{b}$ & $0 \%(0)_{\mathrm{c}}$ \\
\hline $\begin{array}{l}\text { Intellectual } \\
\text { disability }\end{array}$ & $19.5 \%(394)_{a}$ & $14.9 \%(120)_{b}$ & $10.6 \%(10)_{c}$ & $5.0 \%(13)_{c}$ \\
\hline $\begin{array}{l}\text { Emotional behavior } \\
\text { disability }\end{array}$ & $8.5 \%(|7|)_{a}$ & $8.4 \%(200)_{a}$ & $27.7 \%(26)_{b}$ & $13.7 \%(36)_{c}$ \\
\hline $\begin{array}{l}\text { Hearing } \\
\text { impairment }\end{array}$ & $0.1 \%(3)_{a}$ & $1.9 \%(46)_{b}$ & $0 \%(0)_{a, b}$ & $0 \%(0)_{a, b}$ \\
\hline Noncategorical & $1.5 \%(31)_{a}$ & $1.5 \%(36)_{a}$ & $2.1 \%(2)_{a}$ & $1.5 \%(4)_{\mathrm{a}}$ \\
\hline $\begin{array}{l}\text { Orthopedic } \\
\text { impairment }\end{array}$ & $\mathrm{I} .4 \%(29)_{\mathrm{a}}$ & $0.8 \%(20)_{a}$ & $0 \%(0)_{a}$ & $0 \%(0)_{a}$ \\
\hline $\begin{array}{l}\text { Other health } \\
\text { impairments }\end{array}$ & $37.3 \%(752)_{a}$ & $36.6 \%(869)_{a}$ & $38.3 \%(36)_{a}$ & $48.5 \%(127)_{b}$ \\
\hline $\begin{array}{l}\text { Significant } \\
\text { developmental } \\
\text { disability }\end{array}$ & $0 \%(\mathrm{I})_{\mathrm{a}}$ & $0 \%(0)_{a}$ & $0 \%(0)_{a}$ & $0 \%(0)_{a}$ \\
\hline $\begin{array}{l}\text { Specific learning } \\
\text { disability }\end{array}$ & $27.4 \%(552)_{a}$ & $29.5 \%(699)_{a}$ & $14.9 \%(14)_{b}$ & $30.5 \%(80)_{a}$ \\
\hline $\begin{array}{l}\text { Speech or language } \\
\text { impairment }\end{array}$ & $0.4 \%(8)_{a}$ & $0.4 \%(9)_{a}$ & $0 \%(0)_{a}$ & $0.8 \%(2)_{a}$ \\
\hline $\begin{array}{l}\text { Traumatic brain } \\
\text { injury }\end{array}$ & $0.6 \%(13)_{a}$ & $0.5 \%(13)_{a}$ & $0 \%(0)_{a}$ & $0 \%(0)_{a}$ \\
\hline Visual impairment & $0.1 \%(3)_{a}$ & $0.3 \%(6)_{a}$ & $0 \%(0)_{a}$ & $0 \%(0)_{a}$ \\
\hline
\end{tabular}

Note. Value in parentheses refers to number of students. Means with differing subscripts within rows are significantly different at $p<.05$.

(29.1\%). There is no significant difference between female student enrollment in traditional and academic remediation-focused alternative schools (48.7\%). The proportional difference of male enrollment between traditional (53.5\%) and innovative alternative schools (49.3\%), and between traditional and behavior-focused alternative schools (70.9\%) is significant. In addition, there is significant difference in male distribution between innovative and behavior-focused alternative schools.

\section{Ethnicity}

The overall test statistic for race/ethnicity across school types is significant, $\chi^{2}(15, N=21162)=492.97, p=.000$. Details of the differences between the four school types are provided in the sections below. 
African American. African American student distribution is significantly different between traditional (61.2\%) and behavior-focused alternative schools $(81.2 \%)$, and between traditional and academic remediation-focused alternative schools $(87.0 \%)$. There is no significant difference in the proportion of African American students attending traditional and innovative schools $(59.9 \%)$. However, there is significant difference in distribution between innovative and behavior-focused alternative schools, and between innovative and academic remediation-focused alternative schools.

Asian. Asian student representation differs significantly between traditional $(5.8 \%)$ and behavior-focused alternative schools $(0.6 \%)$ as well as between traditional and academic remediation-focused alternative schools $(0.9 \%)$. Similarly, there is a significant difference in Asian student representation between innovative $(6.1 \%)$ and behavior-focused or academic remediationfocused alternative schools. There is no significance in the difference in Asian student representation between traditional and innovative alternative schools.

Hawaiian Islander/Pacific Islander. Hawaiian Islander or Pacific Islander student proportions do not significantly differ across school types.

Hispanic. The proportion of Hispanic students differs significantly between traditional (22.8\%) and innovative alternative schools (20.4\%), between traditional and behavior-focused alternative schools $(9.7 \%)$, and between traditional and academic remediation-focused alternative schools (7.3\%). Similarly, there is significant difference in proportions between innovative and behavior-focused, and between innovative and academic remediationfocused alternative schools.

Native American. Native American student distribution is not significantly different across school types.

White. White student distribution is significantly different between traditional $(9.3 \%)$ and innovative alternative schools $(13.0 \%)$, and between traditional and academic remediation-focused alternative schools (4.3\%). Furthermore, there is significant difference between innovative and behavior-focused (7.3\%), and innovative and academic remediation-focused alternative schools.

\section{FRL Qualification}

The overall test statistic for FRL across school types is significant, $\chi^{2}(3, N=$ $21162)=227.08, p=.000$. The distribution of FRL students for each school 
type - traditional school (85.1\%), innovative alternative school $(76.9 \%)$, behavior-focused alternative school (66.1\%), and academic remediationfocused alternative school (80.6\%) - is significantly different. Similarly, each school type's FRL distribution differs significantly when it is compared with each of the other three school types.

\section{Disability Status}

The overall test statistic for disability status across school types is also significant, $\chi^{2}(3, N=21162)=137.39, p=.000$. In addition, the overall test statistic for special education eligibility category across school types is significant, $\chi^{2}(33, N=4744)=175.85, p=.000$. Here, we highlight the significant differences between special education eligibility category distribution and school type (see Table 4 for complete representation of all categories).

Autism. The proportion of students receiving special education services under the autism label is significantly different between traditional $(2.9 \%)$ and innovative alternative schools $(5.1 \%)$. The difference in percentage of students with autism also differs significantly between traditional and behaviorfocused alternative schools $(6.4 \%)$.

Emotional behavior disability (EBD). The proportion of students receiving special education services under the EBD label is significantly different between behavior-focused alternative schools (27.7\%) and traditional (8.5\%), innovative alternative $(8.4 \%)$, and academic remediation-focused alternative $(13.7 \%)$ schools. In addition, the distribution difference is significant between academic remediation-focused alternative schools and traditional or innovative alternative schools.

Intellectual disability (ID). The proportion of students receiving special education services under the ID label is significantly different across all four school types. There is a significantly lower distribution of students with ID in innovative alternative schools (14.9\%) compared with traditional schools $(19.5 \%)$. In addition, the distribution is significantly lower in both behavior-focused $(10.6 \%)$ and academic remediation-focused (5.0\%) alternative schools when compared with both traditional and innovative alternative schools.

Other health impairments $(\mathrm{OHI})$. The distribution of students receiving special education services under the $\mathrm{OHI}$ label is significantly different between traditional $(37.3 \%)$ and academic remediation-focused alternative schools $(48.5 \%)$. In addition, the distribution is significantly different between 
academic remediation-focused and innovative (36.6\%) alternative schools. There is no significant difference between behavior-focused $(38.3 \%)$ and academic remediation-focused alternative schools.

Specific learning disability (SLD). The distribution of students receiving services under the SLD category is significantly lower in the behavior-focused alternative school (14.9\%) than in the other three school types. Tests of significance for differences between the remaining three settings were not significant.

\section{Discussion and Implications}

The purpose of this study was to analyze enrollment patterns with regard to student gender, ethnicity, SES status, and disability status in one urban school district. Specifically, this cross-sectional analysis addressed whether the proportions of students enrolled in different types of secondary schools, including traditional and three alternative models, vary significantly. For issues related to gaps in achievement and equality of educational opportunity, it is important to consider the spectrum of school settings available to students and their families and the ways in which districts use them. The type of school a student attends often denotes the educational opportunities and academic and social experiences they are afforded or denied. For example, research suggests that attending either behavior-focused or academic remediation-focused alternative schools is associated with disparate student outcomes compared with attending innovative or traditional school settings (Chiang \& Gill, 2010; Wilkerson et al., 2016). Similarly, characteristics of schools-including mission, size, and location-have profound impact on immediate student achievements as well as have postschool implications (Owyang \& Vermann, 2012). If there are predictable patterns of enrollment in different types of schools, understanding which students are more likely to be served in which contexts is of paramount importance. In today's climate of outcome accountability and increasing concern with gaps in school and postschool outcomes between subgroups of students, variation in academic and social contexts needs to be an area of inquiry if we are to move closer to providing equitable opportunities for success to all youth. Knowing that students' experiences and outcomes can vary across school types, it was with educational equity in mind that we examined these enrollment distributions.

\section{Enrollment Size Across School Type}

Data from this study correspond with previous research (see National Alliance for Public Charter Schools, 2013; Rebarber \& Zgainer, 2014), indicating a 
trend toward increasing district reliance on innovative, public charter and partnership schools. However, because traditional schools, in general, house more students, they still account for a relatively high percentage of student enrollment. In our study, the average enrollment in each of the nine traditional high schools was more than 900 students. This enrollment figure is significantly greater than the average enrollment in each of the sample district's innovative alternative schools, which was 563 students. Therefore, when a student attends an innovative alternative school, he or she conceivably has access not only to an innovative curriculum or pedagogy but also to a smaller school learning community. Given the evidence that smaller schools are associated with increased student involvement, warmer relationships between students and staff, healthier school climates and in turn generally better academic outcomes including attendance and grade point averages (Cotton, 2001; Lee \& Burkham, 2003; McNeely, Nonnemaker, \& Blum, 2002; Stevenson, 2006) and the fact that student demographics are significantly different across these two types of schools, it may be difficult to disentangle which characteristics (i.e., size, pedagogy, curriculum) are most responsible for any positive benefits associated with innovative alternative settings. Examining the performance and experiences of students in innovative alternative schools would be highly beneficial to research aimed at improving outcomes for all students.

By contrast, the average enrollment in academic remediation and behaviorfocused schools is much smaller (i.e., 88 and 18, respectively). While some studies have demonstrated positive characteristics associated with behavior and academic remediation-focused alternative schools in terms of locales for credit catch-up (e.g., Dupper, 2006; Franklin, Streeter, Kim, \& Tripodi, 2007; Prevatt \& Kelly, 2003), other studies have implied significant drawbacks related to attending these schools. Studies by Lehr and Lange (2003a, 2003b) and Dynarski and Gleason (1998) suggest that retaining students in remediation-based alternative settings can be difficult and that school exit is often premature, which has lasting implications for those students who leave without a diploma. In addition, there is evidence that students' academic performance, measured by both grade point average and standardized test scores, may decrease following enrollment in an alternative school designed for academic recovery (Carruthers \& Baenen, 1997; Dugger \& Dugger, 1998; Tenenbaum, 2000). Similarly, a longitudinal study of academic outcomes associated with behavior-focused alternative schools reported worse outcomes for students in terms of attendance and credit accrual compared with outcomes for a matched sample of students from traditional schools (Wilkerson et al., 2016). 
It is also important to note that although students enrolled in behaviorfocused or academic remediation-focused alternative schools have access to smaller class sizes and may have increased opportunities to earn catch-up credits at a faster pace than in other school types, a caveat to credit recovery is that the delivery is often geared toward "getting it over with" and "quick-fix"- which are associated with content memorization and regurgitation rather than meaningful learning (J. H. Kim \& Taylor, 2008, p. 23). This form of curricular emphasis is in sharp contrast to that which is typically found in traditional or innovative alternative schools. When the intent is to earn credits quickly perhaps at the cost of critical learning, students are at significant disadvantage - both in terms of knowledge gained and consistency with peers in other schools - which may be a reason that transition back to a traditional school from a behavior-focused or academic remediation-focused alternative school is typically difficult and met with decreased performance by the student in transition.

This research suggests limits to the positive relationship between small school size and achievement for high school students when mission and scope of the school are considered. While it is beyond the intent of this study to empirically attest to the outcomes of students attending alternative schools, we hope that the results of our research will spur review and consideration of student outcomes across school types, keeping in mind mission, curricula, size, and location.

\section{Differences in Gender by School Type}

Results of this study indicate female secondary students attend innovative alternative schools in higher proportion than traditional high schools and behavior-focused or academic remediation-focused alternative schools. Yet the most troubling finding regarding gender differences in enrollment is the high proportion of males attending behavior-focused schools. For those young men enrolled in settings in which behavior modification is of primary concern, the curriculum they receive and their schooling experience likely differ substantially from those which are offered in typical high schools. By attending these schools, which may be considered "last chance" or even "soft jail" destinations (Raywid, 1994, p. 27), students are educated in a nearly allmale environment, surrounded by students who experience similar struggles and who have been deemed problematic. A caution to settings that exclusively serve individuals presenting difficult or deviant behaviors is that the stigmatization and lack of access to positive peer models tend to further compound students' risk for negative outcomes (e.g., dropout, delinquency, and incarceration; Chapin \& Griffin, 2005; Redding, Lexcen, \& Ryan, 2005). 
Our findings also correspond with research on gender performance disparity within K-12 environments. For example, Long and Conger (2013a, $2013 \mathrm{~b}$ ) found that female K-12 students are more likely to be educated in settings which demand higher achievements, including more rigorous charter or voucher schools. Similarly, this work indicates an overrepresentation of male K-12 students in nontraditional schools, such as those affiliated with special education services or juvenile justice programming. Long and Conger (2013a) suggested that disproportionate gender representation and the achievements associated with different settings may be linked to the increasing gender gap and increasing female enrollment in colleges and universities - that perhaps it is the differing opportunities for male and female students during their K-12 trajectory that influence this gap in postsecondary choices and success. Furthermore, our study corresponds with Long and Conger's (2013a, 2013b) assertion that gender sorting in regard to school placement is more significant in locations or districts that offer greater variance in school types (i.e., settings that target higher performing and lower performing students).

\section{Race/Ethnicity Across School Type}

For the less represented race and ethnicity groups in the district (i.e., Asian and Hawaiian or Pacific Islander), there is little disparity in distribution across school types. However, for the larger represented race and ethnicity groups, this study reveals significant differences. African American and Hispanic students are enrolled disproportionately in both behavior-focused and academic remediation settings. Compared with the total district percentage (62.3\%), African American youth are significantly overrepresented in both behavior-focused (81.2\%) and academic remediation-focused (87.0\%) alternative schools and underrepresented in innovative alternative school (59.9\%). Concurrently, Hispanic students are significantly underrepresented in behavior-focused $(9.7 \%)$ and academic remediation-focused $(7.3 \%)$ alternative schools when compared with total district percentage $(20.5 \%)$ and underrepresented in innovative alternative schools (20.4\%) when compared with traditional school percentage (22.8\%).

The overrepresentation of African American students in academically and behaviorally remedial settings, and their underrepresentation in innovative settings, is concerning and correlates with past research, which indicates African American youth are more likely than any other racial and ethnic demographic to be removed from a traditional, general education setting (Gonzalez \& Szecsy, 2004; Skiba, Michael, Nardo, \& Peterson, 2002; Skiba \& Peterson, 1999; Skiba

$\&$ Rausch, 2006). Due to evidence of disparate outcomes for students enrolled 
in behavior-focused and academic remediation-focused alternative schools, this disproportionality is especially concerning. Furthermore, students removed from traditional, general education settings and relocated to more restrictive and segregated placements for reasons related to poor behavior are at increased risk for school disengagement, dropout, and psychosocial effects such as feelings of alienation, depression, and worthlessness (Brown, 2007; Chapin \& Griffin, 2005; Redding et al., 2005; Sekayi, 2001; Wald \& Kurlaender, 2003; Wald \& Losen, 2003). Many of these experiences, such as dropping out and depression, have negative lifelong implications on an individual's employability, family dynamics, and association with judicial systems such as juvenile corrections or prison (e.g., Sum, Khatiwada, McLaughlin, \& Palma, 2009).

Indeed, the overrepresentation of African Americans involved in the U.S. court system is hypothesized as a phenomenon strongly related to schooling and school placement trajectories in elementary through high school. Referred to frequently as the "school to prison pipeline" (e.g., Bahena, Cooc, CurrieRubin, Kuttner, \& Ng, 2012; Christle, Jolivette, \& Nelson, 2005), the association between schooling in K-12 settings and juvenile detention or adult corrections has been linked to disproportionate application of exclusionary discipline procedures, such as detention and alternative school referral, toward African American youth. Rather than support academic success, these practices push students away from their classrooms and into the outer folds society and thus into the grasp of the criminal justice system (Bahena et al., 2012; Christle et al., 2005; Fenning \& Rose, 2007; C. Kim, Losen, \& Hewitt, 2010; Lerner \& Galambos, 1998; Skiba et al., 2002; Wald \& Losen, 2003; Zeiderberg \& Schiraldi, 2002). Because of the association between exclusion from traditional schools, educational services in restrictive settings, and increased risk for negative outcomes, the results of our study, which indicate significant overrepresentation of African American students in academic remediation-focused and behavior-focused alternative schools, are concerning and underscore an urgent need to look closer at the alternative school referral processes.

Enrollment patterns for Hispanic students reveal different, yet also potentially problematic, distributions as well. Compared with traditional school proportions $(22.8 \%)$, Hispanic youth are underrepresented in innovative (20.5\%), behavior-focused (9.7\%), and academic remediation-focused (7.3\%) alternative schools. In addition, Asian students are underrepresented in behavior-focused $(0.6 \%)$ and academic remediation-focused $(0.9 \%)$ alternative schools compared with traditional school enrollment (5.8\%) and total district percentage (5.6\%). If ethnicity plays a role in preventing Hispanic and Asian students from identification for remedial assistance, if an authentic need exists, then underrepresentation in behavior-focused and academic 
remediation-focused alternative schools may in fact be a barrier to essential services.

The fact that both Hispanic and African American students are underrepresented in innovative schools while White students are overrepresented (13.0\%) compared with their total percentage in the district (11.0\%) and their total percentage in traditional schools $(9.3 \%)$ indicates White youth have greater opportunity to attend schools associated with increased academic rigor, unique pedagogy, and curricular innovation. Innovative alternative schools tend to provide environments in which students are engaged in critical thinking, self-determination, and community partnerships (e.g., Raywid, 1990, 1994), and these settings often require competitive application to attend (a process associated with capital). Thus, it merits questioning why enrollment disparities exist and reflection on its relationship to postschool outcome gaps between student subgroups. For example, we know that the structure and organization of the four school types (i.e., traditional, innovative, behavior-focused, and academic remediation-focused) are different from one another, and that structure and organization of educational settings have been linked to students' engagement or subsequent dropout (e.g., Lee \& Burkham, 2003). We also know that there are differences in school retention, credit accrual, and completion rates between school types (e.g., Wilkerson et al., 2016); thus, it appears the overrepresentation of White students in innovative alternative schools reflects inequality of optimal opportunity between racial and student ethnic groups.

Commenting on issues prevalent in urban schooling, Tyack (1976) posited that access to quality - or optimal-education can "create and legitimate elites" (p. 365). Similarly, Bowles and Gintis (2011) suggested that the differences in K-12 academic and social experiences perpetuate postschool social inequality and hierarchal racial relationships. Recent employment and income statistics, including rates of unemployment and annual earnings, indicate that the disparity between African American and White households is rapidly growing (see Shapiro, Meschede, \& Osoro, 2013). Therefore, in discussion of enrollment distribution across urban schools today, it is imperative to examine and answer to the discrepancies which allow some students greater access to an optimum education - as disparate educational experiences prepare students to take their places "in a class structure in which power is unequally divided" (Tyack, 1976, p. 383).

\section{SES Across School Type}

Nationally, $68.2 \%$ of secondary students in U.S. public schools qualify for FRL (U.S. Department of Education, National Center for Education Statistics, 
2010). In our sample, $80.4 \%$ of the students qualified, yet it is not uncommon for urban districts to have higher percentages of students who qualify (U.S. Department of Education, National Center for Education Statistics, 2010). In our study, there are significant differences in the proportions of students who qualify for FRL across each school type. Given the racial and ethnic representation differences, we might have expected to find lower percentages of FRL in innovative alternative schools than in behavior-focused or academic remediationfocused alternative schools as the association between race and ethnicity and SES is widely documented (e.g., Shapiro et al., 2013). However, our results indicate that the percentage of students who qualify for FRL in behaviorfocused alternative schools $(66.1 \%)$ is lower than in innovative alternative schools $(76.9 \%)$. There is difference in percentages between traditional (85.1\%) and innovative alternative schools - which does corroborate with the racial and ethnic disparity between the two settings. Noted differences in FRL qualification across all school types merit further investigation.

\section{Disability by School Type}

The proportion of students receiving special education services in our district sample $(22.4 \%)$ is high compared with the national average $(13.0 \%$; U.S. Department of Education, National Center for Education Statistics, 2014). In regard to individual school types, proportions are similar between traditional and innovative alternative schools (23.8\% and $21.2 \%$, respectively). By contrast, more than half $(57.0 \%)$ of students who attend behavior-focused alternative schools receive special education services, whereas academic remediation-focused alternative schools have the lowest representation of students who receive special education services (19.7\%). This pattern suggests that school professionals pursue the option of placing students with disabilities in segregated settings more readily when the students exhibit behavior problems - but are less apt to refer students with disabilities to settings that focus on academics. This is an unexpected pattern and deserves

further consideration to gain a better understanding of educator beliefs and dispositions related to the referral of students with disabilities to alternative settings.

Considering specific disability categories, students with EBD had the highest representation in behavior-focused alternative schools (27.7\%). This leads us to consider the possibility that students with EBD labels are not being adequately served through special education in more traditional school settings, and are thus relocated disproportionately to alternative placements charged with behavior remediation. The distribution of EBD is also significantly high in academic remediation-focused alternative schools (13.7\%), underscoring the 
comorbid relationship among academic and behavioral difficulty. This finding corresponds with research that identifies greater risk of subsequent academic and behavioral problems for students who present in one area prior to the other (e.g., Rutherford, Quinn, \& Mathur, 2004). An additional finding is that academic remediation-focused alternative schools serve a significantly higher proportion of students with an $\mathrm{OHI}(48.5 \%)$, in which attention deficit hyperactivity disorder is an included label, compared with the other three school types. Discussions of equality or equity of educational opportunity should include consideration of the specific needs of students with disabilities relative to their placement in educational environments. Locales in which students with disabilities are educated (e.g., separate classrooms or separate schools), can have profound impact on those students' experiences during their schooling and postschooling trajectories (e.g., Bak, Cooper, Dobroth, \& Siperstein, 1987; Bianco, 2005; Powell \& Planck, 2003). Considering placement in restrictive and segregated settings during K-12 increases the risk for greater segregation or restriction in adulthood, we should be cautious with further marginalization of youth with disabilities into segregated school programs.

\section{Conclusion and Limitations}

Our cross-sectional analysis of enrollment across four different school types (i.e., traditional, innovative, behavior-focused, and academic remediationfocused) reveals significant differences in certain demographic characteristics of students who attend each type. These enrollment distributions suggest that subgroups of students are referred to or choose to attend alternative schools in disproportionate rates compared with total district percentages. In particular, African American students and students with disabilities are overrepresented in behavior-focused and academic remediation-focused alternative schools, and White students are overrepresented in innovative alternative schools. Overrepresentation of African American and White students in different school types is concerning and represents possible pathways to disparate opportunities for school achievement. For example, behavior-based and remediation-based restrictive settings are associated with lower expectations and "quick-fix" credit recovery - these are the settings in which African American students are overrepresented. Simultaneously, White students are underrepresented in them. On the opposite spectrum, White students are overrepresented in innovative alternative schools, which tend to provide an enriched learning environment. In regard to gender, it appears that female students have greater access to innovative settings, whereas male students are overrepresented in schools charged with modifying behavior. Furthermore, the disparity of disability status across school types implies that larger 
percentages of students with disabilities are relocated to behavior-focused and academic remediation-focused settings. Discrepancies in these enrollment patterns across school types suggest inequitable access to certain educational opportunities for different groups of students, which may mirror the societal inequalities to which youth are subjected in their communities.

A limitation of our study is that we analyze data from only one district. Further analysis of enrollment trends of other, similar districts would strengthen the generalizability of our findings. In addition, because each district differs in regard to policies and procedures employed by administrators and school staff, which may impact the types of schools offered as well as enrollment practices, we need to consider the unique contexts of individual school districts when interpreting results from this and similar studies. We acknowledge the existence of small percentage of the student population who may use alternative education to their advantage in other ways (e.g., boost grade point average for college entrance). Because our data do not attest to the specific intentions of each individual in the student sample, it is unfeasible to account for all the reasons students enroll in alternative education beyond pursuit of innovation or behavior and academic remediation. Finally, because students are able to, and do, transition between one alternative school to another, such as from a behavior-focused to an academic remediation-focused setting, a longitudinal study in this or another urban district examining school type movement in regard to race, gender, SES, and disability could significantly add to the existing research in alternative education and drop-out prevention.

\section{Declaration of Conflicting Interests}

The author(s) declared no potential conflicts of interest with respect to the research, authorship, and/or publication of this article.

\section{Funding}

The author(s) received no financial support for the research, authorship, and/or publication of this article.

\section{References}

Bahena, S., Cooc, N., Currie-Rubin, R., Kuttner, P., \& Ng, M. (2012). Disrupting the school to prison pipeline. Cambridge, MA: Harvard Educational Review.

Bak, J. J., Cooper, E. M., Dobroth, K. M., \& Siperstein, G. N. (1987). Special class placements as labels: Effects on children's attitudes toward learning handicapped peers. Exceptional Children, 54, 151-155.

Bianco, M. (2005). The effects of disability labels on special education and general education teachers' referrals for gifted programs. Learning Disability Quarterly, 28, 285-293. 
Bifulco, R., Ladd, H., \& Ross, S. (2009). Public school choice and integration evidence from Durham, North Carolina. Social Science Research, 38, 71-85.

Bowles, S., \& Gintis, H. (2011). Schooling in capitalist America: Educational reform and the contradictions of economic life. Chicago, IL: Haymarket Books.

Brown, T. M. (2007). Lost and turned out: Academic, social, and emotional experiences of students excluded from school. Urban Education, 42, 432-455.

Carruthers, W., \& Baenen, N. (1997). Did the alternative educational program for students with long-term suspensions make a difference? (Report No. 98). Raleigh, NC: Wake County Public School System, Department of Evaluation and Research.

Chapin, D. A., \& Griffin, P. A. (2005). Juvenile diversion. In K. Heilbrun, S. Goldstein, \& R. Redding (Eds.), Juvenile delinquency: Prevention, assessment, and intervention (pp. 161-178). New York, NY: Oxford University Press.

Chiang, H., \& Gill, B. (2010). Student characteristics and outcomes in alternative and neighborhood high schools in Philadelphia. Cambridge, MA: Mathematica Policy Research.

Christle, C. A., Jolivette, K., \& Nelson, M. (2005). Breaking the school to prison pipeline: Identifying school risk and protective factors for youth in delinquency. Exceptionality: A Special Education Journal, 13, 69-88.

Cotton, K. (2001). New small learning communities: Findings from recent literature. Portland, OR: Northwest Regional Educational Laboratory.

Davis, T. M. (2012). School choice and segregation: "Tracking" racial equity in magnet schools. Education and Urban Society, 46, 399-433.

Dugger, J. M., \& Dugger, C. W. (1998). An evaluation of a successful alternative high school. The High School Journal, 81, 218-228.

Dupper, D. R. (2006). Guides for designing and establishing alternative school programs for dropout prevention. In C. Franklin, M. B. Harris, \& P. Allen-Meares (Eds.), The school services sourcebook: A guide for school-based professionals (pp. 397-404). New York, NY: Oxford University Press.

Dynarski, M., \& Gleason, P. (1998). How can we help? What we have learned from evaluations of federal dropout prevention programs. Princeton, NJ: Mathematica Policy Research.

Fenning, P., \& Rose, J. (2007). Overrepresentation of African American students in exclusionary discipline: The role of school policy. Urban Education, 42, 536-559.

Franklin, C., Streeter, C. L., Kim, J. S., \& Tripodi, S. J. (2007). The effectiveness of a solution-focused public alternative school for dropout prevention and retrieval. Children \& Schools, 29, 133-144.

Gold, M., \& Mann, D. W. (1982). Alternative schools for troublesome secondary students. The Urban Review, 14, 305-316.

Gonzalez, J. M., \& Szecsy, E. M. (2004). The condition of minority access and participation in Arizona: 2004. Retrieved from http://epsl.asu.edu/aepi/EPSL-0405108-AEPI.pdf

Henig, J. (1996). The local dynamics of choice: Ethnic preferences and institutional responses. In R. Elmore, B. Fuller, \& G. Orfield (Eds.), Who chooses? Who loses? Culture, institutions, and the unequal effects of school choice (pp. 95-117). New York, NY: Teachers College Press. 
Keaton, P. (2014). Selected statistics from the public elementary and secondary education universe: School year 2012-13 (NCES 2014-098). Washington, DC: U.S. Department of Education, National Center for Education Statistics. Retrieved from http://nces.ed.gov/pubsearch

Kim, C., Losen, D., \& Hewitt, D. (2010). The school to prison pipeline. New York: New York University Press.

Kim, J. H., \& Taylor, K. A. (2008). An alternative for whom? Rethinking alternative education to break the cycle of educational inequality and inequity. The Journal of Educational Research, 101, 207-219.

Lee, V. E., \& Burkham, D. T. (2003). Dropping out of high school: The role of school organization and structure. American Educational Research Association, 40, 353-393.

Lehr, C. A., \& Lange, C. M. (2003a). Alternative schools and the students they serve: Perceptions of state directors of special education (Policy research brief). Minneapolis: University of Minnesota, Institute on Community Integration.

Lehr, C. A., \& Lange, C. M. (2003b). Alternative schools serving students with and without disabilities: What are the current issues and challenges? Preventing School Failure, 47, 59-65.

Lehr, C. A., Tan, C. S., \& Ysseldyke, J. (2009). Alternative schools: A synthesis of state-level policy and research. Remedial and Special Education, 30, 19-32.

Lerner, R. M., \& Galambos, N. L. (1998). Adolescent development: Challenges and opportunities for research, programs, and policies. Annual Review of Psychology, 49, 413-443.

Lippman, L., Burns, S., \& McArthur, E. (1996). Urban schools: The challenge of location and poverty. Washington, DC: U.S. Department of Education, Office of Educational Research and Improvement.

Long, M. C., \& Conger, D. (2013a). Gender gaps in college enrollment: The role of gender sorting across public high schools. Educational Researcher, 42, 371-380.

Long, M. C., \& Conger, D. (2013b). Gender sorting across K-12 schools in the United States. American Journal of Education, 119, 349-372.

McCurdy, B. L., Kunsch, C., \& Reibstein, S. (2007). Secondary prevention in the urban school: Implementing the behavior education program. Preventing School Failure, 51, 12-19.

McNeely, C. A., Nonnemaker, J. M., \& Blum, R. (2002). Promoting school connectedness: Evidence from the National Longitudinal Study of Adolescent Health. Journal of School Health, 72, 138-146.

National Alliance for Public Charter Schools. (2013). Dashboard: A comprehensive data resource from the NAPCS: Total number of public charter schools. Retrieved from http://www.publiccharters.org/dashboard/reports

No Child Left Behind (NCLB) Act of 2001, 20 U.S.C.A. $§ 6301$ et seq. (West 2003).

Owyang, M., \& Vermann, K. (2012). Measuring the effect of school choice on economic outcomes. The Regional Economist, 4. Retrieved from http://www.stlouisfed.org/publications/re/articles/?id=2284 
Powell, J., \& Planck, M. (2003). Constructing disability and social inequality early in the life course: The case of special education in Germany and the United States. Disability Studies Quarterly, 23, 57-75.

Prevatt, F., \& Kelly, F. D. (2003). Dropping out of school: A review of intervention programs. Journal of School Psychology, 41, 377-385.

Raywid, M. (1990, November). Alternative education: The definition problem. Changing Schools, pp. 25-33.

Raywid, M. (1994). Alternative schools: The state of the art. Educational Leadership, 5, 26-31.

Rebarber, T., \& Zgainer, A. C. (2014). Survey of America's charter schools. Retrieved from https:/www.edreform.com/wp-content/uploads/2014/02/2014CharterScho olSurveyFINAL.pdf

Redding, R. E., Lexcen, F. J., \& Ryan, E. P. (2005). Mental health treatment for juvenile offenders in residential psychiatric and juvenile justice settings. In K. Heilbrun, S. Goldstein, \& R. Redding (Eds.), Juvenile delinquency: Prevention, assessment, and intervention (pp. 282-309). New York, NY: Oxford University Press.

Renzulli, L., \& Evans, L. (2005). School choice, charter schools, and white flight. Social Problems, 52, 398-418.

Rutherford, R. B., Quinn, M. M., \& Mathur, S. R. (2004). Handbook of research in emotional and behavioral disorders. New York, NY: Guilford Press.

Saporito, S. (2003). Private choices, public consequences: Magnet school choice and segregation by race and poverty. Social Problems, 50, 181-203.

Sekayi, D. N. R. (2001). Intellectual indignation: Getting at the roots of student resistance in an alternative high school program. Education, 122, 414-422.

Shapiro, T., Meschede, T., \& Osoro, S. (2013). The roots of the widening racial wealth gap: Explaining the black-white economic divide. Retrieved from http:// iasp.brandeis.edu/pdfs/Author/shapiro-thomas-m/racialwealthgapbrief.pdf

Skiba, R., Michael, R. S., Nardo, A. C., \& Peterson, R. (2002). The color of discipline: Sources of racial and gender disproportionality in school punishment. Urban Review, 34, 317-341.

Skiba, R., \& Peterson, R. (1999). The dark side of zero tolerance: Can punishment lead to safe schools? Phi Delta Kappan, 80, 372-376, 381-382.

Skiba, R., \& Rausch, M. K. (2006). Zero tolerance, suspension, and expulsion: Questions of equity and effectiveness. In C. M. Evertson \& C. S. Weinstein (Eds.), Handbook of classroom management: Research, practice, and contemporary issues (pp. 1063-1092). Mahwah, NJ: Lawrence Erlbaum.

Stevenson, K. R. (2006). School size and its relationship to student outcomes and school climate: A review and analysis of eight South Carolina state-wide studies. Retrieved from http://www.ncef.org/pubs/size_outcomes.pdf

Sum, A., Khatiwada, I., McLaughlin, J., \& Palma, S. (2009). The consequences of dropping out of high school: Joblessness and jailing for high school dropouts and the high cost for taxpayers (Paper No. 23). Retrieved from http://iris.lib.neu. edu/cgi/viewcontent.cgi?article $=1022 \& ;$ context $=$ clms_pub

Tenenbaum, I. M. (2000). What is the penny buying for South Carolina? Sixteenth annual reporting on the South Carolina Education Improvement Act of 1984. Columbia: South Carolina State Board of Education. 
Tyack, D. (1976). Ways of seeing: An essay on the history of compulsory schooling. Harvard Educational Review, 46, 355-389.

U.S. Department of Education, National Center for Education Statistics. (2010). Status and trends in the education of racial and ethnic minorities (NCES 2010015). Washington, DC: U.S. Government Printing Office.

U.S. Department of Education, National Center for Education Statistics. (2014). The condition of Education 2014 (NCES 2014-083). Washington, DC: U.S. Government Printing Office.

Verdugo, R., \& Glenn, B. (2006). Race and alternative schools: The new tracking. Washington, DC: Hamilton Fish Institute on School and Community Violence.

Wald, J., \& Kurlaender, M. (2003). Connected in Seattle? An exploratory study of student perceptions of discipline and attachments to teachers. New Directions for Youth Development: Theory, Practice, and Research, 99, 35-54.

Wald, J., \& Losen, D. J. (2003). Editors' notes. In J. Wald \& D. J. Losen (Eds.), New directions for youth development: Deconstructing the school-to-prison pipeline (pp. 1-2). San Francisco, CA: Jossey-Bass.

Wilkerson, K. L., Afacan, K., Perzigian, A. B., Justin, W., \& Lequia, J. (2016). Behavior-focused alternative schools: Impact on student outcomes. Behavioral Disorders, 41, 81-94.

Zeiderberg, J., \& Schiraldi, V. (2002). Cellblocks or classrooms? The funding of their education and corrections and its impact on African American men. Washington, DC: Justice Policy Institute.

\section{Author Biographies}

Aaron B. Perzigian is an assistant professor in the Department of Special Education and Education Leadership at Western Washington University. He is a former special educator with experience in behavior-focused alternative schools and residential treatment centers. His research interests surround alternative education and socialemotional experiences of students with disabilities.

Kemal Afacan is a doctoral student in special education at the University of Wisconsin-Madison. He completed his master's of science degree in special education from the same institution and his bachelor's degree from Karadeniz Technical University in Turkey. His research interests involve alternative education and reading instruction for students with intellectual disabilities.

Whitney Justin is currently a special educator in the Madison Metropolitan School District, in Madison, Wisconsin. During this study, she was completing her master's of science degree in special education at the University of Wisconsin-Madison.

Kimber L. Wilkerson is a professor in the Department of Rehabilitation Psychology and Special Education at the University of Wisconsin-Madison. Her work focuses on enhancing outcomes for students with disabilities. This includes investigating the efficacy of alternative education settings and examining accountability policies on the delivery of special education services. 